\title{
First record of the rare freshwater alga Tetrasporopsis fuscescens (Chrysomerophyceae, Ochrophyta) in North America
}

\author{
Rosalina Stancheva ${ }^{1, *}$, Pavel ŠKaloud ${ }^{2}$, Martin Pusztai ${ }^{2}$, Chad L. Loflen ${ }^{3} \&$ \\ Robert G. SHEATH ${ }^{1}$
}

\author{
${ }^{1}$ Department of Biological Sciences, California State University San Marcos, San Marcos, California 92096, \\ USA; *Corresponding author; fax 1-760-750-3063; e-mail: rhristov@csusm.edu \\ ${ }^{2}$ Department of Botany, Charles University in Prague, CZ-12800 Prague, Czech Republic \\ ${ }^{3}$ California Water Quality Control Board, San Diego Region, 2375 Northside Dr., Suite 100, San Diego, California \\ 92108, USA
}

\begin{abstract}
This study presents the first record of the ochrophyte alga Tetrasporopsis fuscescens in North America, confirmed with light and transmission electron microscopic photomicrographs, cytochemical and molecular phylogenetic analyses. T. fuscescens was recorded rarely, being found in the benthos of only twelve stream sites: nine locations in Southern California and three in Northern California. More than half of the streams were non-perennial, characterized by long dry periods. Tetrasporopsis cells were gold-colored, spherical, with a distinct wall, assembled in the periphery of macroscopical gelatinous colonies, which start as tubular or sac-like structures, but later become membranous. The cells have 1-2 parietal chloroplasts, without a stigma or pyrenoid, and reproduction occurs by longitudinal cell division. Other features of the genus are as follows: cells in the colonies also divide by what appears to be smaller autospores with remnant cell walls remaining, the colonial mucilage consists of cylindrical dichotomously branched tubes radiating from the center of the colony to which attach the peripheral cells, and older cells become filled with large oil droplets. A combined gene tree of sequences from nuclear SSU rDNA, plastid rbcL, psaA, psbA and psbC showed that $T$. fuscescens specimens from Europe and U. S. A. formed a clade, which clustered with taxa classified in the class Chrysomerophyceae.
\end{abstract}

Key words: Tetrasporopsis, Ochrophyta, streams, California, morphology, ecology, phylogeny

\section{INTRODUCTION}

In the last decade, the extensive stream bioassessment sampling of the State of California's Water Resource Control Board Surface Water Ambient Monitoring Program (SWAMP) has provided over two thousand benthic algal samples collected across the entire state. Taxonomic analysis of the data led to the first light microscope (LM) documented record of Tetrasporopsis Lemmerm. ex Schmidle from streams in California in on-line identification guide to over 800 freshwater soft-bodied algal taxa (see Stancheva et al. 2016). The studied stream algal flora had been enriched with many new-to-science species belonging to the green algae Zygnema C.A. Agardh (STAnCHEvA et al. 2012), Spirogyra Link (Stancheva et al. 2013), Ochlochaete Thwaites (Hall et al. 2018) and diatoms Amphora Ehr. ex Kütz., Halamphora (Cleve) Levkov (StEPANEK \& KocioleK 2013), Rhoicosphenia Grunow (ThOMAS \& KocIOLEK 2015), Gomphonema Grunow, Gomphoneis
Cleve (Stancheva et al. 2016), Fallacia Stickle et D. G. Mann (Stancheva \& MANoylov 2018), Cocconies Ehr., Planothidium Round et Bukhtiyarova (STANCHEVA 2019 a, b), as well as the first record of the freshwater brown alga Pleurocladia lacustris A. Braun (WeHR et al. 2013).

The genus Tetrasporopsis is little known and challenging to identify, due to its rare records from freshwaters ponds or slow-running waters in central Europe (TsCHERMAK-Woess 1979; TsCHERMAK-WoESS \& KUSEL-FetZMANN 1992) and Australia (ENTWISLE \& ANDERSEN 1990; ENTwiSLE et al. 1997). Its thallus consists of gold-colored, spherical cells with a distinct wall assembled in colonies, which start as tubular or sac-like structures, but later become membranous (ENTWISLE \& ANDERSEN 1990; GUIRY \& GUIRY 2019). The cells have 1-2 parietal chloroplasts, without a stigma or pyrenoid. Reproduction occurs by longitudinal division and flagella have not been observed. The records of T. fuscescens from the U.S.A. (e.g., ENTWISLE et al. 1997) are uncertain due to confusion with the similar genus Dermatochrysis 
(ENTWISLE \& ANDERSEN, personal communication) and are questioned by NiCHOLLS \& WUJEK (2015).

The type species, Tetrasporopsis fuscescens (A. Braun ex Kütz.) Lemmerm. was first collected from Freiburg, Germany by A. Braun in November 1846, and this specimen was consequently leptotypified by ENTWISLE \& ANDERSEN (1990), who re-evaluated the protologues and described a new genus Dermatochrysis T. J. Entwisle et R. A. Andersen to include algae resembling Tetrasporopsis, but lacking cell walls. T. fuscescens was illustrated with either LM or transmission electron microscope (TEM) images from streams in Portugal (as Chrysocapsa epiphytica Lund) (Mesquita \& SANTos 1976a, 1976b), Austria (TsCHERMAK-Woess 1979; TSCHERMAK-WoESS \& KuSEL-FETZMAnN 1992) and Australia (ENTWISLE \& ANDERSEN 1990; ENTWISLE et al. 1997). This species is regarded as a rare, early-spring species in cool, slow-running streams and pools in central Europe (KRISTIANSEN \& PreISIG 2001) and desiccation-tolerant in non-perennial streams in Australia (ENTwisle \& ANDERSEN 1990). T. fuscescens from a Portuguese study (originally identified as Chrysocapsa epiphytica Lund by MESQUITA \& SANTOS 1976a, 1976b) was deposited at the Culture Collection of Algae at Goettingen University, strain SAG 20.88, and consequently used for phylogenetic analyses (KAI et al. 2008; ICHINOMIYA et al. 2011) and fatty acid profile studies (LANG et al. 2011). The phylogenetic position of Tetrasporopsis is still unclear with placement in Chrysophyceae (ENTwISLE \& ANDERSEN 1990; GUIRY \& GuIRY 2019), Phaeothamniophyceae (BAILEY et al 1998; KRISTIANSEN \& PREISIG 2001; ICHINOMIYA et al. 2011), and Chrysomerophyceae (KAI et al. 2008).

The aims of this paper were to: 1) report the distribution and ecological preferences of Tetrasporopsis in streams and rivers in California, 2) to provide morphological (LM), ultrastructural (TEM) and cytochemical characterization of this species, and 3 ) to determine its taxonomic affinities based on molecular phylogenetic analysis.

\section{Materials AND Methods}

Field Sampling. The samples came from a major survey of over 2,000 wadeable streams across California that have been sampled for benthic algae and environmental variables under dry season (low-flow) conditions from March to October from 2008 to 2017. Quantitative composite benthic algal samples were collected from whatever substrata were present (e.g., cobble, silt/sand, gravel, bedrock, wood) at 11 objectively selected locations, spaced evenly across a 150 or $250 \mathrm{~m}$ long stream reach. In addition, fresh grab algal samples and environmental variables were obtained using a multi-habitat sampling protocol (ODE et al. 2016a). In addition, for the purposes of this study we collected fresh Tetrasporopsis colonies from Cottonwood Creek (902NP9CWC on March 20, 2017) and Bell Creek (901BELOLV on May 12, 2017) in Southern California and from the South Fork of Eel River (August 29, 2017) in Northern California (Table 1).

Water Level Logger Deployment. Stream flow duration and depth were recorded in seven non-perennial streams in Southern California, where Tetrasporopsis was observed, using Onset $\mathrm{HOBO}{ }^{\circledR}$ U20 pressure transducer loggers (Onset Computer Corporation, Bourne, MA (Table 2). Loggers were deployed in the fall for 2-4 year period to target the onset and duration of flow prior to sampling. Loggers were deployed in locations indicative of sustained active baseflow (e.g. runs or glides, not pools and riffles) to prevent the over or under-estimation of flows and represent conditions required for the collectionof benthic stream algae across multiple in-stream habitats. Loggers were set to record at 6-hour intervals to capture diel variability. Above-water $\mathrm{HOBO} \otimes \mathrm{U} 20$ pressure transducers were deployed outside the streambed at a subset of sites, selected on a regional basis, to enable for water level correction calculations per manufacturer's recommendations. Water depth and flow onset and drying times were calculated in $\mathrm{HOBOware}{ }^{\circledR}$ at each site after barometric compensation using data from a proximate above-water logger combined with reference water depths measured by field crews during stream sampling, logger deployment, and/or flow reconnaissance. Calculations in HOBOware ${ }^{\circledR}$ were exported to Microsoft Excel (Microsoft 2012) for calculations of stream intermittency calculated as stream dry period between flows. Dry periods were calculated as the number of days the logger continuously recorded no flow without inter-period wetting events, with wetting event being defined as 24 hours of stream flow (e.g. perennial streams would be 0 dry days).

LM. Algal photomicrographs, thallus and cell dimensions in this study were obtained from fresh specimens only. LM analysis and imaging of the specimens was performed using an Olympus ${ }^{\circledR}$ BX41 Photomicroscope and Olympus ${ }^{\circledR}$ SZ61 Stereomicroscope (Olympus America Inc., Center Valley, Pennsylvania) with differential interference contrast optics and attached Olympus ${ }^{\circledR}$ SC30 Digital Camera.

Cytochemistry. Lugol's and Methylene Blue staining was used to display the structure of extracellular colonial mucilage (Krishnamurthy 1999). Intracellular phenolic compounds were stained with toluidine blue O staining (O'Brien et al. 1964). Toluidine blue $\mathrm{O}(0.05 \%) \mathrm{pH} 4.5$ stains polysaccharides rich in carboxyl or sulfate groups pink to reddish purple, and phenolic compounds green to bright blue (O'Brien and McCully 1981). Nile red fluorescent stain was applied to confirm the presence of intracellular lipid droplets (Greenspan et al. 1985). Nile red fluorescence of lipids (yellow-gold) was observed with an Olympus IX50 inverted fluorescence microscope using blue excitation (420-490 $\mathrm{nm}$ filter).

All cytochemistry observations were conducted on fresh Tetrasporopsis colonies from Bell Creek, and Lugol's staining was applied to all Tetrasporopsis specimens studied. All chemicals used were from Fisher Scientific, Pittsburg, PA, USA. TEM. Fresh Tetrasporopsis colonies from Eel River were used for TEM observations. Colonies were fixed with $2 \%$ glutaraldehyde in $0.1 \mathrm{M}$ cacodylate buffer and postfixed in $1 \%$ $\mathrm{OsO}_{4}$ in $0.1 \mathrm{M}$ cacodylate buffer for $1 \mathrm{hr}$ on ice. The colonies were dehydrated in graded series of ethanol $(50-100 \%)$ while remaining on ice. They were then subjected to one wash with $100 \%$ ethanol and 2 washes with acetone (10 min each) and embedded with Durcupan. Sections were cut at $60 \mathrm{~nm}$ on a Leica UCT ultramicrotome, and picked up on 300 mesh copper grids. Sections were post-stained with $2 \%$ uranyl acetate for 5 minutes and Sato's lead stain for 1 minute. Grids were viewed using FEI Tecnai Spirit G2 BioTWIN TEM and photographed with a bottom mount Eagle $4 \mathrm{k}$ (16 mega pixel) camera (Hillsboro, OR) at the Department of Cellular and Molecular Medicine at University of California San Diego. 
Molecular phylogenetic analysis. Fresh Tetrasporopsis samples from Bell Creek were sent to Charles University in Prague for sequencing. Additionally, strain SAG 20.88 Tetrasporopsis spec. (as Chrysocapsa epiphytica (MesQuita \& SANTos 1976a, 1976b) was sequenced for comparison.

DNA isolations were carried out as described in ŠKALOUDOVÁ \& ŠKALOUD (2013) with the only difference in using of $30 \mathrm{ml}$ of InstaGene matrix (Bio-Rad Laboratories). Five molecular markers were amplified by PCR: nuclear SSU rDNA, plastid rbcL, psaA, psbA and psbC. The amplification of SSU rDNA was performed as described by ŠKALOUD et al. (2013), using the primers 18SF and 18SR (Katana et al. 2001) and newly designed primers Chryso SSU F2 (5'-TGT CTC AAA GAT TAA GCC AT-3') and Chryso_SSU_R2 (5'-CTA CGG AAA CCT TGT TAC GA-3'), annealing at $47^{\circ} \mathrm{C}$. The amplification of the rbcL marker was performed according to Jo et al. (2011) using newly designed primers Chryso_rbcL_F4 (5'-TGG ACD GAY TTA TTA ACD GC-3') and Chryso_rbcL_R7 (5'-CCW CCA CCR AAY TGT ARW A-3'), annealing at $46{ }^{\circ} \mathrm{C}$. The amplifications of the psaA and psbA markers were performed according to Yoon et al. (2002) using primers psaA 130F (5'-AAC WAC WAC TTG GAT TTG GAA-3') and psaA 1760R (5'- CCT CTW CCW GGW CCA TCR CAW GG-3') for psaA and primers psbA F $\left(5^{\prime}-\right.$ ATG ACT GCT ACT TTA GAA AGA CG $\left.-3^{\prime}\right)$ and psbA R2 (5'- TCA TGC ATW ACT TCC ATA CCT A - $3^{\prime}$ ) for psbA. The amplification of the psbC marker was performed according to YANG et al. (2012) using primers psbC $31 \mathrm{~F}\left(5^{\prime}-\mathrm{TAC}\right.$ CAC GTG GAA ACG CYC T-3') and psbC 1160R (5'- TCT TGC CAH GGY TGD ATA TCA-3'). The PCR products were purified and sequenced at Macrogen Inc. in Seoul, Korea or in Amsterdam, The Netherlands.

The dataset consisted of concatenated 35 SSU rDNA, $35 \mathrm{rbcL}, 26 \mathrm{psaA}, 21 \mathrm{psbA}$, and $16 \mathrm{psbC}$ sequences, selected to encompass all lineages within the Stramenopiles SI and SII clades (YANG et al. 2012). The SSU rDNA sequences were aligned and cured using MAFFT, version 6, applying the Q-INS-i strategy (KATOH et al. 2002). Then, poorly aligned positions were eliminated using the program Gblocks, version 0.91b (Talavera \& CASTREsana 2007). The final alignment was $1506-b p$ long. The remaining sequences were manually aligned using MEGA 5 (Tamura et al. 2011). The final alignments were 1323-bp (rbcL), 1365-bp (psaA), 855-bp (psbA) and 1020-bp (psbC) long, respectively. Prior concatenating the genes into final datasets, NJ analyses were performed on separate loci in MEGA 5 to check for possible topological incongruencies.

The most appropriate partition-specific substitution models were selected by jModelTest 2.1.4. The BIC-based model selection procedure selected the following models: (1) $\mathrm{SYM}+\mathrm{I}+\Gamma$ for SSU rDNA, (2) $\operatorname{TrN}+\mathrm{I}+\Gamma$ for the $1^{\text {st }}$ rbcL and $3^{\text {rd }}$ psaA codon partitions, (3) $\mathrm{JC}+\mathrm{I}+\Gamma$ for the $2^{\text {nd }}$ rbcL codon partition, (4) TVM $+\mathrm{I}+\Gamma$ for the $3^{\text {rd }} \mathrm{rbcL}$ and $2^{\text {nd }}$ psaA codon partitions, (5) GTR $+\Gamma$ for the $1^{\text {st }}$ psaA and $\mathrm{psbC}$ codon partitions, (6) TVM + I for the $1^{\text {st }}$ and $3^{\text {rd }}$ psbA codon partitions, (7) $\mathrm{JC}+\mathrm{I}$ for the $2^{\text {nd }} \mathrm{psbA}$ codon partition, (8) K80 $+\mathrm{I}$ for the $2^{\text {nd }}$ psbC codon partition, and (9) TIM1 $+\Gamma$ for the $3^{\text {rd }}$ psbC codon partition. The phylogenetic trees were inferred with Bayesian inference (BI) by using MrBayes version 3.2.6 (RONQUIST \& HUELSENBECK 2003), carried out on partitioned dataset to differentiate among both genes and codon positions. The GTR substitution model was applied instead of SYM, TrN, TVM and TIM1, given that it was the best matching model available in MrBayes. All parameters were unlinked among partitions. Two parallel Markov chain Monte Carlo (MCMC) runs were carried out for 8 million generations each with one cold and three heated chains. Trees and parameters were sampled for every 100 generations. Convergence of the two cold chains was checked and "burnin" was determined by use of the "sump" command. Bootstrap analyses were performed by ML and weighted parsimony (wMP) criteria by using GARLI, version 2.0 (ZwICKL 2006) and PAUP, respectively. ML analyses consisted of 100 replicates, using default settings and the automatic termination set at 500,000 generations. The analyses were run on partitioned dataset to differentiate among both genes and codon positions, using the substitution models as described above. The wMP bootstrapping (1,000 replicates) was performed using heuristic searches with 1000 random sequence addition replicates, TBR swapping, and random addition of sequences (the number was limited to 10,000 for each replicate). The weight to the characters was assigned using the rescaled consistency index on a scale of $0-1,000$. New weights were based on the mean of the fit values for each character over all of the trees in memory.

\section{RESULTS}

Tetrasporopsis was rarely recorded during the course of this multi-year extensive state-wide study of California. We identified this genus in twelve sites from nine streams located in southern California, and three in northern California (Table 1).

Seven of the streams in Southern California were documented as non-perennial with long dry periods recorded (Table 2), ranging from a few months per year, typically from late spring to early winter, to up to three continuous years for sites 902NP9CWC and 911NP9SCC, preceding the development of Tetrasporopsis. The water parameters in Tetrasporopsis sites were $\mathrm{pH} 7-8$, temperature $10-23.8^{\circ} \mathrm{C}$, low salinity $(0-0.1 \mathrm{ppt})$ and conductivity (30.9-183.1 $\mu{\left.\mathrm{S} . \mathrm{cm}^{-1}\right)}$ in sites in Northern California, and elevated salinity $(0.2-0.76 \mathrm{ppt})$ and conductivity

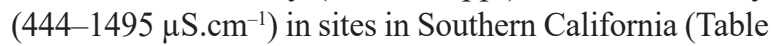
1). Tetrasporopsis colonies were growing in quantities along the shaded areas of the stream reach attached to rocks, wood, roots, water plants.

\section{LM observations}

Colonies were up to $4 \mathrm{~cm}$ long, gelatinous, brownish, and started as sac-like structures (Fig.1A-B), but later became lobate, tubular or membranous, but not perforated. Cells were mostly concentrated in a layer within 5-15 $\mu \mathrm{m}$ from the outer surface of the monostromatic thallus, but the inner part of the mucilage also contained a few cells. Cells were randomly spaced in the periphery, more or less spherical, and 6.3-12 $\mu \mathrm{m}$ in diameter (Fig. $1 \mathrm{C}-\mathrm{D})$, whereas the cells in the inner part of the colony were ovoid and up to $16 \mu \mathrm{m}$ long. Each cell has a distinct wall (Fig. 1D), two to four yellow-brown parietal chloroplasts, several chrysolaminarin granules and oil droplets (Fig 1E). The cell wall was clearly visible in cells with degraded protoplasts (Fig. 1C). Contractile vacuoles, stigma and pyrenoids were not observed. In the young colonies from Cottonwood Creek, the common 


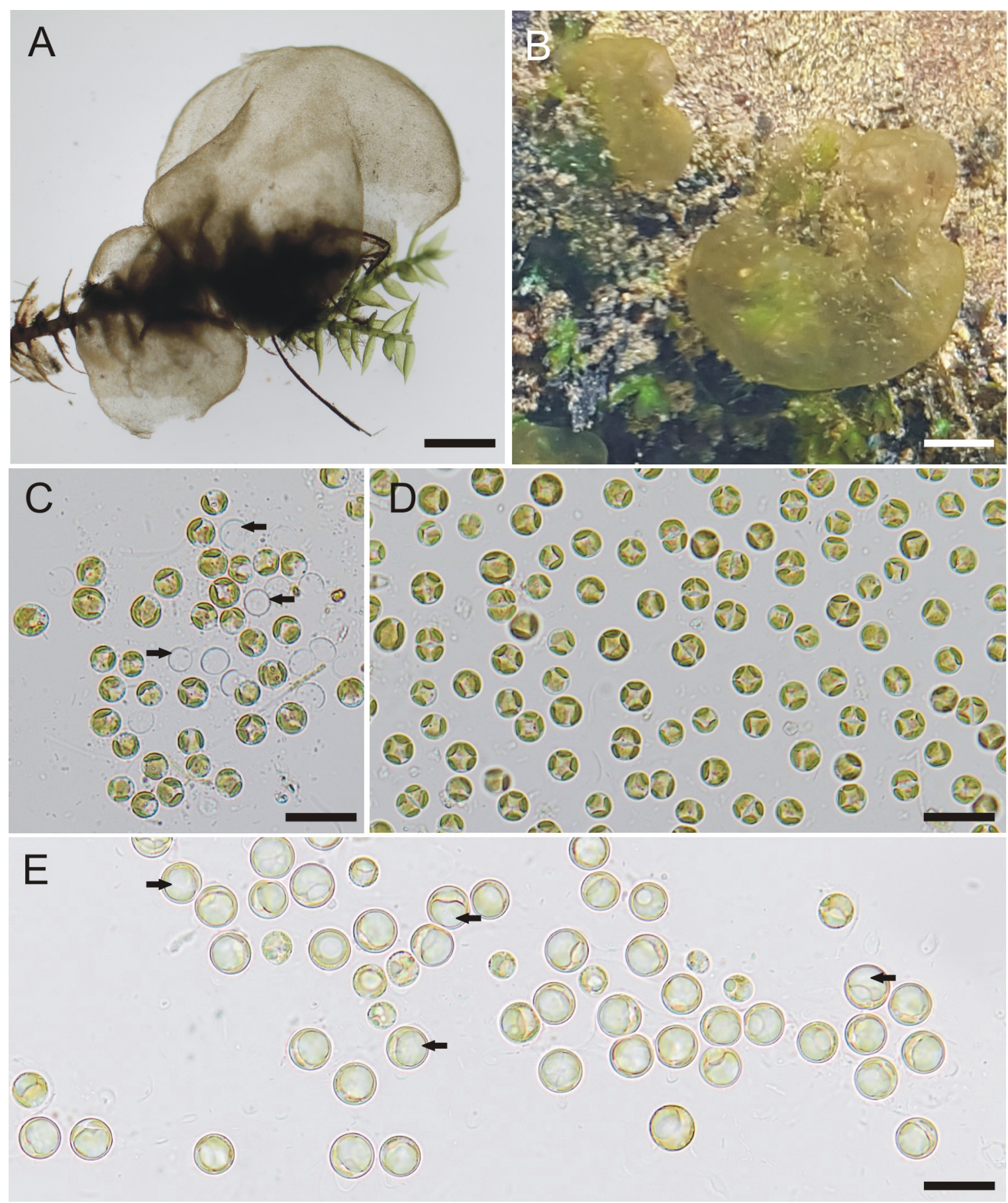

Fig. 1. Tetrasporopsis fuscescens field-collection: (A) Two globular colonies attached to an aquatic moss (Bell Creek); (B) Several benthic colonies in situ (Eel River); (C) Spherical cells with 2 or 3 parietal chloroplasts and situated in the outer colonial mucilage; (D) Remnant cell walls (arrows) scattered among vegetative cells; (E) Older cells in which much of the cell volume is filled with oil droplets (arrows). Scale bars $1 \mathrm{~cm}(\mathrm{~A}-\mathrm{B}), 20 \mu \mathrm{m}(\mathrm{C}-\mathrm{E})$.

mucilage was diffuse and colorless, and small refractive particles with Brownian motion were visible in actively dividing cells with diameter up to $10 \mu \mathrm{m}$. In the older larger colonies from Bell Creek, in some of the colonial lobes, many cells were larger than $10 \mu \mathrm{m}$ in diameter and were embedded in the lower gelatinized part of the older cell wall in connection with mucilage production and condensation. The cell wall remnants were visible on the top of the cell. The oil droplets in these cells were enlarged and often merged into large single drop occupying large portions of the protoplast (Fig. 1E). These non-dividing cells were distributed among few actively dividing cells. Many spherical cells with diameter about $13 \mu \mathrm{m}$ which were almost completely filled with large vacuole containing with gelatinous putative chrysolaminaran. The refractive particles with Brownian motion were missing from the enlarged cells with increased amount of storage products. 

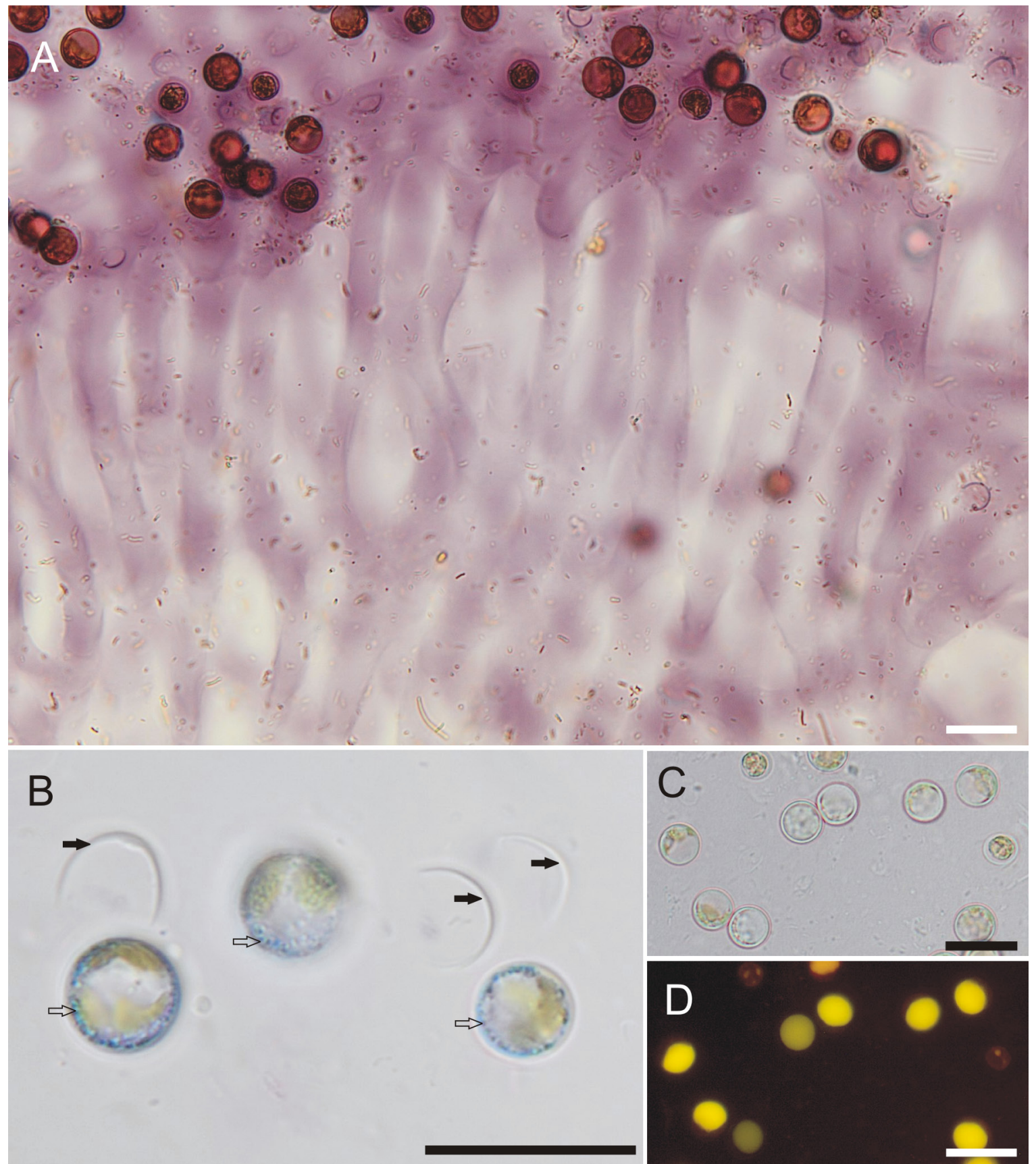

Fig. 2. Tetrasporopsis fuscescens with various staining regimes: (A) Lugol's staining showing the extracellular colonial mucilage which consists of cylindrical tubular dichotomously branched structures radiating from the center of the colony. Each cell is situated on the outer layer of a mucilaginous tube, and the cell division results in tube bifurcation; (B) Cells stained with Toluidine Blue O, showing positive blue stained small bodies in the periphery of the cells (white arrows). Note the presence of remnant cell walls (black arrows); (C) Older cells with large lipid bodies before staining with Nile Red; (D) Same cells with positive Nile Red yellow-colored stain indicating the presence of lipids. Scale bars $20 \mu \mathrm{m}(\mathrm{A}-\mathrm{D})$

Reproduction was by longitudinal cell division to two daughter cells producing new cell walls. The daughter cells departed from each other in a characteristic way, starting from one pole, and the other poles stayed connected for some time with remnants of the mother cell wall. The walls of the mother cells disappeared shortly after division by gelatinization. The morphology of the specimens from California completely agree with the description of T. fuscescens from Australia (Entwisle and Andersen 1990) and Austria (Tschermac-Woess and Kusel-Fetzmann 1992). The capacity of producing zoospores was mentioned by Tschermac-Woess and Kusel-Fetzmann (1992), but not observed in our material; stomatocysts were also not present.

\section{Cytochemical observations}

Lugol's and Methylene Blue staining showed that extracellular colonial mucilage consists of cylindrical tubular dichotomously branched structures radiating from the center of the colony (Fig. 2A). Each cell was 


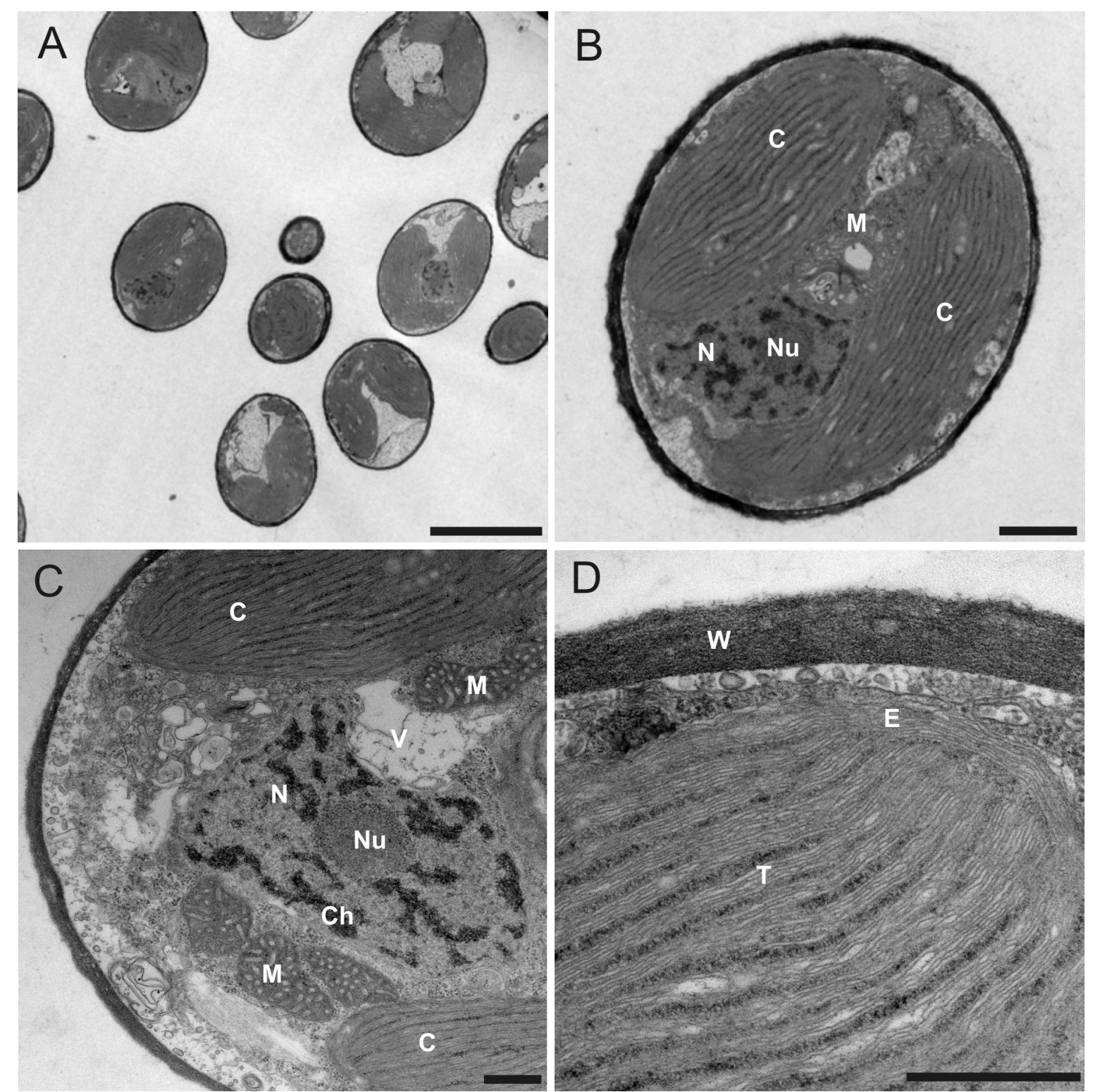

Fig. 3. TEM of Tetrasporopsis fuscescens: (A) Portion of a colony with scattered cells; (B, C) Vegetative cell with two tubular chloroplasts $(\mathrm{C})$, nucleus at one end $(\mathrm{N})$ with a prominent nucleolus $(\mathrm{Nu})$, and condensed chromatin $(\mathrm{Ch})$, several scattered mitochondria $(\mathrm{M})$ and portion of vacuoles (V); (D) Periphery of cell with a chloroplast with several layers of envelope and endoplasmic reticulum (E) and a cell wall with multiple layers of fibrils (W). Scale bars $5 \mu \mathrm{m}$ (A), $1 \mu \mathrm{m}$ (B), $0.5 \mu \mathrm{m}$ (C, D).

situated on the outer layer of a mucilaginous tube, and the cell division resulted in tube bifurcation. Toluidine blue $\mathrm{O}$ stained many small granular structures located in the cell periphery between the chloroplast and cell wall, possibly containing phenolic compounds (Fig. 2B). The number of these blue-greenish stained structures was variable depending on cell development stage. Nile red fluorescent staining confirmed the presence of variable amount of lipids in the cells, depending on cell physiological condition (Fig. 2C-D).

\section{TEM observations}

The cells were unevenly spaced in the outer mucilage with the chloroplasts occupying $2 / 3$ or more of the cell volume (Fig. 3A). The nucleus was situated near one end of the cell and contained a prominent nucleolus and condensed chromatin scattered within the nucleoplasm (Fig. 3B-C). The chloroplast envelope had multiple layers and connects with the cytoplasmic endoplasmic reticulum. The chloroplasts had scattered chains of plastoglobuli, which were presumably lipoidal. The elongate thylakoids were in stacks of three throughout their length (Fig. 3D). The mitochondria were often localized near the nucleus and they had lobe-like cristae (Fig. 3C). The cell contained vacuoles of various sizes which may be part of a larger network (Fig. 3C). The cell wall was thick and composed of multiple layers of fibrils (Fig. 3D).

\section{Molecular phylogenetic analysis}

The combined gene tree of taxa belonging to Stramenopiles 


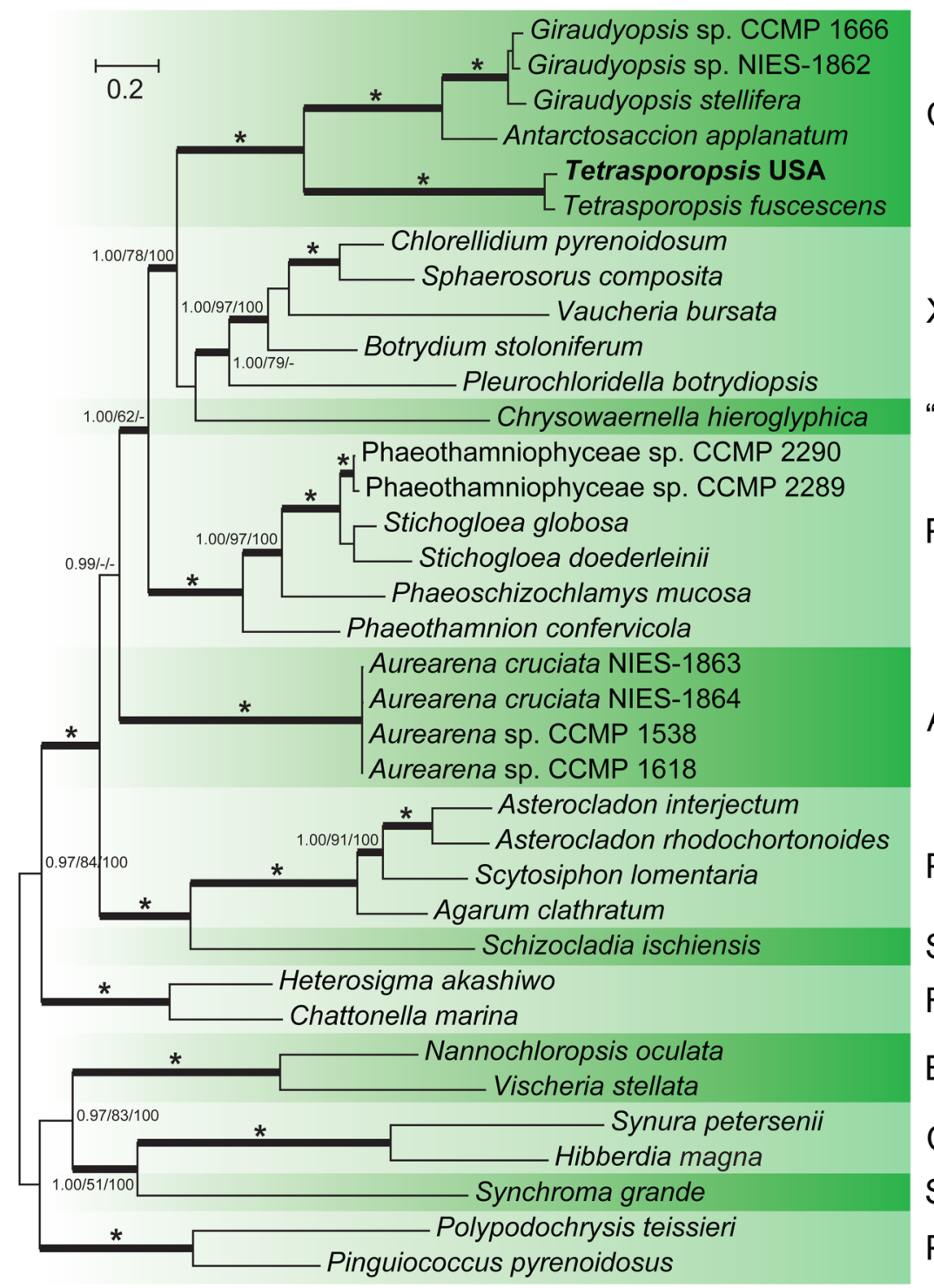

Chrysomerophyceae

Xanthophyceae

"Chrysomerophyceae"

Phaeothamniophyceae

Aurearenophyceae

Phaeophyceae

Schizocladiophyceae

Raphidophyceae

Eustigmatophyceae

Chrysophyceae

Synchromophyceae

Pinguiophyceae

Fig. 4. Bayesian phylogenetic analysis of Stramenopiles clades SI and SII, based on the partitioned dataset of concatenated SSU rDNA, rbcL, psaA, psbA, and psbC sequences. Values at the nodes indicate statistical support estimated by three methods - MrBayes posterior-node probability (left), maximum likelihood bootstrap (middle), and maximum parsimony bootstrap (right). Full statistical support (1.00/100/100) is marked with an asterisk. Thick branches represent nodes receiving the highest PP support (1.00). The scale bar shows the estimated number of substitutions per site.

SI and SII clades (sensu Yang et al. 2012) included Tetrasporopsis in the clade SI (Fig. 4). The two Tetrasporopsis specimens from Europe and U.S.A. formed a distinct clade, which clustered sister to taxa classified in the class Chrysomerophyceae. Tetrasporopsis was separated from the rest of Chrysomerophyceae taxa with quite a long branch.

\section{Discussion}

This study provided evidence for the distribution of desiccation-tolerant, macroscopic stream alga Tetrasporopsis fuscescens in streams in California, U.S.A. Tetrasporopsis was recorded in seven non-perennial stream sites in southern California, with streams being dry for several months prior to collection, or running only in extremely wet years (e.g. 2017, Table 2). While water level loggers were not deployed at the other two southern California sampling locations, stream flow surveys during summer dry periods found the locations to be non-perennial (C. Loflen, personal observation; R. Barabe, personal communication). Similarly, ENTwisLE \& ANDERSEN (1990) recorded T. fuscescens in non-perennial streams in Australia tolerating dry conditions. This alga could tolerate desiccation for long periods, although resting cells with modified cell walls, such as akinetes or silicious statospores, nor sexual reproduction are unknown (ENTWisle \& ANDERSEn 1990, this study). The desiccation tolerance could be attributed to high amounts of phenolic compounds deposited in the periphery of the cell 


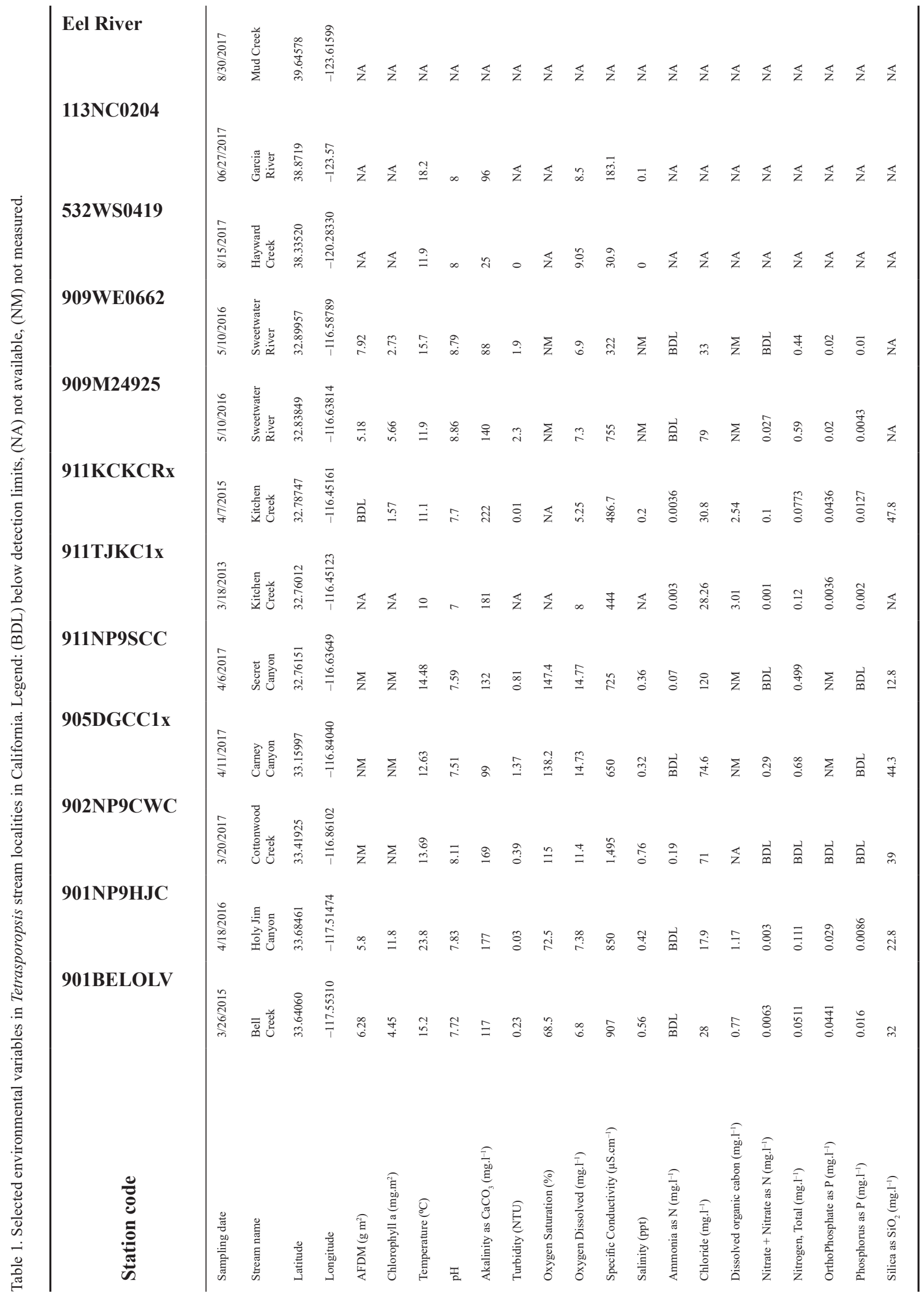




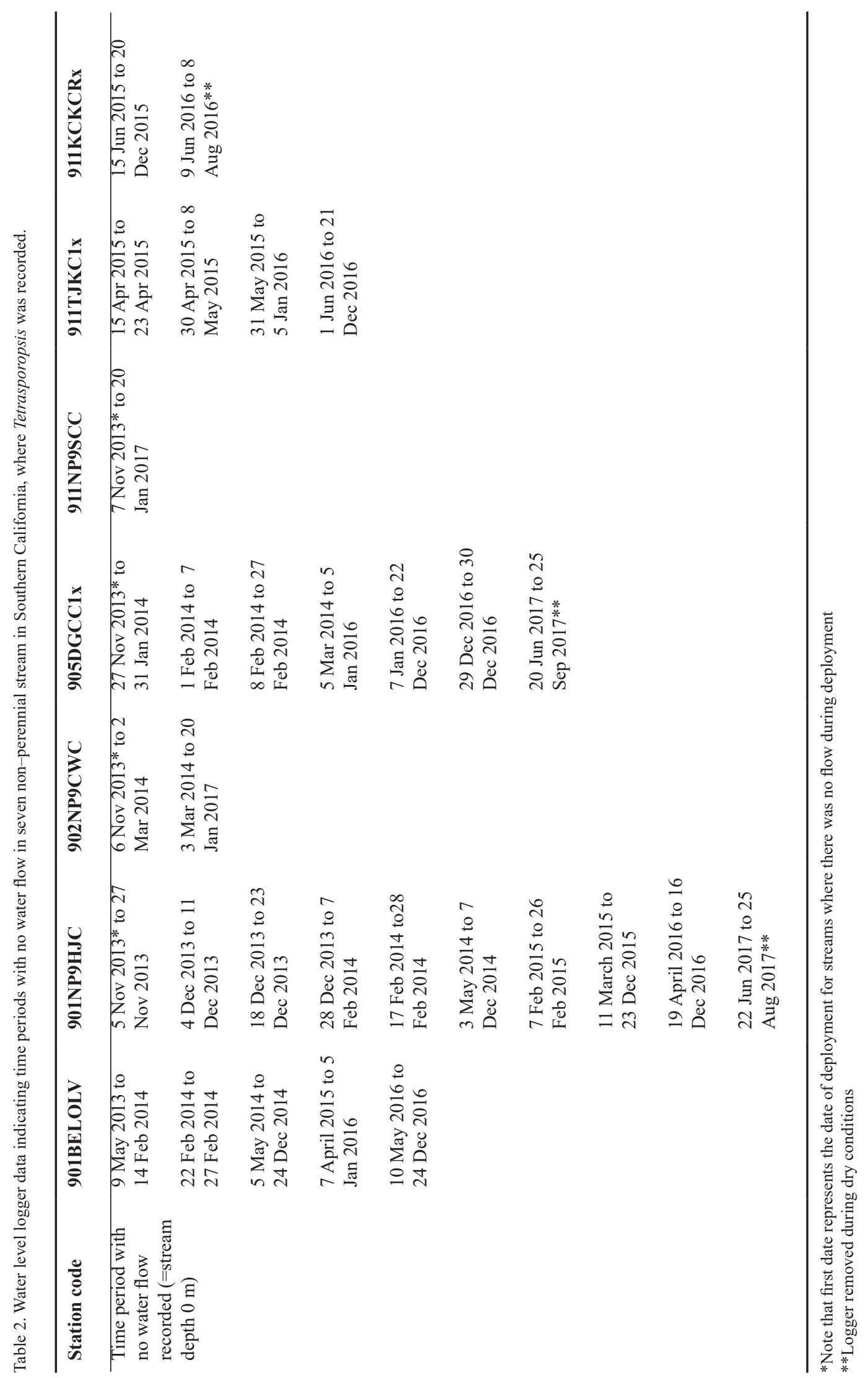


between parietal chloroplasts and cell walls, potentially protecting the intracellular organelles and DNA from UV radiation (Holzinger \& Pithrtová 2016). Also, the formation of multilayered mucilaginous walls, in combination with storing large amounts of lipids. The cells of Tetrasporopsis contain plentiful amounts of reserve products, particularly large lipid globules in older cells. ENTWISLE \& ANDERSEN (1990) called these large structures in their electon micrographs chrysolaminarin vacuoles, but our Nile Red staining in similar structures shows that they are lipoidal, not carbohydrate in content. Storage of lipid bodies is common in a variety of members of Stramenopiles as cells approach stationary phase of growth (BIGELOw et al. 2013).

Tetrasporopsis fuscescens distributed in California is an indicator of good water quality stream conditions based on the nutrient data (Table 1) as well of the fact that it co-exists with red algae Sheathia Salomaki et M. L. Vis and Sirodotia Kylin, and $\mathrm{N}_{2}$-fixing cyanobacterium Nostoc Vaucher ex Bornet et Flahault, which occur in low nutrient waters (STANCHEVA et al. 2016). In addition, the seven logged non-perennial sites in southern California were screened as part of the State of California's Reference Condition Management Program, which targets sites for sampling that meet criteria for a lack of anthropogenic activity upstream (e.g. roads, agriculture, ODE et al. 2016b).

One of the key questions that we had at the onset of this study is its classification among fucoxanthindominated algal groups in Stramenopiles, was answered by our combined gene tree (Fig. 4). Supplementing the dataset by three newly-sequenced plastid-encoded genes (i.e. psaA, psbA and psbC) corroborated the placement of the genus in a sister position to Chrysomerophyceae as already proposed by KAI et al. (2008). For any conclusion concerning the taxonomic placement of Tetrasporopsis, the type species of the genus Chrysomeris, C. ramosa N. Carter, need to be isolated in culture and sequenced, along with comparative ultrastructural, molecular and pigment analyses of both genera.

The genus Tetrasporopsis is a monospecific. However, GUIRY \& GUIRY (2019) consider two more species for the genus, that is, T. perforata (Whitford) Bourrelly (conspecific with $T$. reticulata K. I. Meyer according to WHITFORD 1976) and T. pseudofenestrata J.W.G. Lund. Indeed, both species were transferred to Dermatochrysis by ENTWISLE \& ANDERSEN (1990) and listed as currently accepted Dermatochrysis species by GUIRY \& GUIRY (2019). All of our specimens resemble morphologically the type species T. fuscescens.

\section{ACKNOWLedgements}

The California State Water Resources Control Board Surface Water Ambient Monitoring Program provided funding and data. We are thankful to Deborah Woodward (San Diego Regional Water Quality Control Board) for collecting Tetrasporopsis from non-perennial streams in southern California. We are thankful to Mary Power (Angelo Reserve, University of California Berkeley), Rex Lowe, and Paula Furey who organized the field trip to Eel River where we collected Tetrasporoposis used in this study. We also thank Sandy and Pete DeSimone at Audubon
Starr Ranch for allowing the State of California access for sampling at Bell Creek. Cristina Fuller helped with Tetrasporopsis staining and Kim Conklin with algae sample analysis. Professor R. A. Anderson helped this study with discussions and isolating Tetrasporopsis strain on DY-V medium. We thank Timo Meerloo and Ying Jones at UCSD for the assistance with TEM observations. Access to computing and storage facilities owned by parties and projects contributing to the National Grid Infrastructure MetaCentrum providedunder the programme „Projects of Large Research, Development, and Innovations Infrastructures“ (CESNET LM2015042), is greatly appreciated.

\section{REFERENCES}

Andersen, R. A. (2005): Algal Culturing Techniques. - 578 pp., Elsevier Academic Press, Amsterdam.

Bailey, J.C.; Bidigare, R.R..; Christensen, S.J. \& Andersen, R.A. (1998): Phaeothamniophyceae classis nova: a new lineage of chromophytes based upon photosynthetic pigments, rbcL sequence analysis and ultrastructure. - Protist 149: 245-263.

Bigelow, N.; Barker, J.; Ryken, S; PATterson, J.; Hardin, W.; Barlow, S.; Deodato, C. \& Cattalico, R.A. (2013): Chrysochromulina sp.: A proposed lipid standard for the algal biofuel industry and its application to diverse taxa for screening lipid content. -Algal Research 2: 385-393.

Entwisle, T.J. \& ANDERSEN, R.A. (1990): A re-examination of Tetrasporopsis (Chrysophyceae) and the description of Dermatochrysis gen. nov. (Chrysophyceae): a monostromatic alga lacking cell walls. - Phycologia 29: $263-274$.

Entwisle, T.J.; Sonneman, J.A. \& Lewis, S.H. (1997): Freshwater algae in Australia. - 242 pp., Sainty and Associates Pty Ltd, Potts Point.

EtTl, H. (1978): Xanthophyceae. - In: Ettl, H.; Gerloff, J. \& Heynig, H. (eds): Süsswasserflora von Mitteleurope. Begründer von A. Pascher. Band 3, Teil 1. - pp. [i]-xiv, [1]-530, VEB Gustav Fischer Verlag, Jena.

Greenspan, P.; Mayer, E.P. \& Fowler S.D. (1985): Nile red: a selective fluorescent stain for intracellular lipid droplets. - Journal of Cell Biology 100: 965-973.

GuIRY, M.D. \& GuIRY, G.M. (2019): AlgaeBase. World-wide electronic publication, National University of Ireland, Galway. Available from: http://www.algaebase.org (accessed 15 February 2019).

Hall, J.D.; Stancheva, R.; McCourt, R.M. \& Sheath, R.G. (2018): Ochlochaete incrustans sp. nov., a new species of freshwater ulvophycean from California, U.S.A. Phycologia 57: 465-476.

Holzinger, A. \& Pichrtová, M. (2016): Abiotic stress tolerance in charophyte green algae: new challenges for omics techniques. - Frontiers in Plant Science 7: 678.

ICHINOMIYA, M.; YoshiKaWA, S.; KamiYA, M.; OHкI, K.; TAKAICHI, S. \& KUWATA, A. (2011): Isolation and charcterization of Parmales (Heterokonta/Heterokontophyta/ Stramenopiles) from the Oyahio region, western North Pacific. - Journal of Phycology 47: 144-151.

Jo, B.Y.; ShIN, W.; Boo, S.M.; KIM, H.S. \& Silver, P.A. (2011): Studies on ultrastructure and three-gene phylogeny of the genus Mallomonas (Synurophyceae). - Journal of Phycology 47: 415-425.

Kai, A.; Yoshit, Y.; Nakayama, T. \& InOUye, I. (2008): Aurearenophyceae classis nova, a new class of Heterokontophyta based on a new marine unicellular alga Aurearena cruciata gen. et sp. nov. inhabiting 
sandy beaches. - Protist 159: 435-457.

Katana, A.; Kwiatowski, J.; Spalik, K.; Zakryś, B.; Szalacha, E. \& Szymańska, H. (2001): Phylogenetic position of Koliella (Chlorophyta) as inferred from nuclear and chloroplast small subunit rDNA. - Journal of Phycology 37: 443-451.

KatoH, K.; Misawa, K.; Kuma, K. \& Miyata, T. (2002): MAFFT: a novel method for rapid multiple sequence alignment based on fast Fourier transform. - Nucleic Acid Research 30: 3059-3066.

KrishNAMURTHY, K.V. (1999): Methods in Cell Wall Cytochemistry. - 318 pp., CRC Press, Boca Raton.

Kristiansen, J. \& Preisig, H.R. (2001): Encyclopedia of Chrysophyte genera. - Bibliotheca Phycologica 110: $1-260$.

LANG, I.; HodaC, L.; FrIEdL, T. \& Feussner, I. (2011): Fatty acid profiles and their distribution patterns in microalgae: a comprehensive analysis of more than 2000 strains from the SAG culture collection. - BMC Plant Biology 11: 124.

Mesquita, J.F. \& SANTos, M.F. (1976a): Etudes cytologiques sur les algues jaunes (Chrysophyceae). I. Ultrastructure de Chrysocapsa epiphytica Lund. - Boletim da Sociedade Broteriana 50: 63-98.

Mesquita, J.F. \& SAntos, M.F. (1976b): Cytological studies in golden algae (Chrysophyceae). II. First cytochemical demonstration of peroxisomes in Chrysophyceae (Chrysocapsa epiphytica Lund). Cytobiologie. - European Journal of Cell Biology 14: 38-48.

Nicholls, K.H. \& WuJEK, D.E. (2015): Chrysophyceae and Phaeothamniophyceae. - In: WeHR, J.D.; Sheath, R.G. \& Kociolek, J.P. (eds.): Freshwater Algae of North America, Ecology and Classification. - pp. 537-586, Academic Press, San Diego.

NoRRIS, R.E. (1961): Observations on phytoplankton organisms collected on the N.Z.O.I. Pacific cruise, September 1958. - New Zealand Journal of Science 4: 162-188.

O’Brien, T.P.; FedER, N. \& MCCulLY, M E. (1964): Polyehromatic staining of plant cell walls by Toluidine Blue O. Protoplasma 59: 368-373.

O’Brien, T.P. \& McCully, M.E. (1981): The Study of Plant Structure: Principles and Selected Methods. - 1-317 pp., Blackwell Scientific Publishing, Oxford.

Ode, P.R.; Fetscher, A.E. \& Busse, L.B. (2016a): Standard Operating Procedures for the Collection of Field Data for Bioassessments of California Wadeable Streams: Benthic Macroinvertebrates, Algae, and Physical Habitat. California State Water Resources Control Board Surface Water Ambient Monitoring Program (SWAMP) Bioassessment SOP 004. Available from: https://drive. google.com/file/d/0B40pxPC5g-D0MS1zMjNacnJZOEk/ view

Ode, P.R.; Rehn, A.C.; Mazor, R.D.; Schiff, K.C.; Stein, E.D., MaY, J.T.; Brown, L.R., HerbSt, D.B.; Gillett, D.; LunDE, K. \& Hawkins, C.P. (2016b): Evaluating the adequacy of a reference-site pool for ecological assessments in environmentally complex regions. Freshwater Science 35: 237-248.

Ronquist, F. \& Huelsenbeck, J.P. (2003): MrBayes 3: Bayesian phylogenetic inference under mixed models. - Bioinformatics 19: 1572-1574.

Sheath, R.G. \& Cole, K.M. (1992): Biogeography of stream macroalgae in North America. - Journal of Phycology 28: 448-460

ŠKaloud, P.; Kristiansen, J. \& ŠKaloudová, M. (2013):
Developments in the taxonomy of silica-scaled chrysophytes - from morphological and ultrastructural to molecular approaches. - Nordic Journal of Botany 31: 385-402.

ŠKaloudová, M. \& ŠKaloud, P. (2013): A new species of Chrysosphaerella (Chrysophyceae: Chromulinales), Chrysosphaerella rotundata, sp. nov., from Finland. - Phytotaxa 130: 34-42.

Stancheva, R.; Fetscher, A.E. \& Sheath, R.G. (2012): A novel quantification method for stream-inhabiting, non-diatom benthic algae, and its application in bioassessment. - Hydrobiologia 684: 225-239.

StANChEVA, R. \& MANOYLOv, K.M. (2018): Fallacia californica sp. nov. (Bacillariophyta), a new freshwater diatom species from streams in California, USA. - Phytotaxa 345: 104-118.

Stancheva, R. (2019a): Cocconeis cascadensis, a new monoraphid diatom from mountain streams in northern California, USA. - Diatom Research 33: 471-483.

Stancheva, R. (2019b): Planothidium sheathii, a new monoraphid diatom species from rivers in California, USA. - Phytotaxa 393: 131-140.

Stancheva, R.; Busse, L.; Kociolek, J.P. \& Sheath, R.G. (2015): Standard Operating Procedures for Laboratory Processing and Identification of Stream Algae. California State Water Resources Control Board Surface Water Ambient Monitoring Program (SWAMP) Bioassessment SOP 0003. Available from: https://www.waterboards. ca.gov/water issues/programs/swamp/bioassessment/ docs/sop_algae_lab_101315.pdf. Accessed February 20, 2019

Stancheva, R.; Fuller, C. \& Sheath, R.G. (2016): Soft-Bodied Stream Algae of California. Available from: http:// dbmuseblade.colorado.edu/DiatomTwo/sbsac_site/ index.php. Accessed May 23, 2018.

Stancheva, R., Hall, J.D. \& ShEATH, R.G. (2012): Systematics of the genus Zygnema (Zygnematophyceae, Charophyta) from Californian watersheds. - Journal of Phycology 48: 409-422.

Stancheva, R.; Hall, J.D.; McCourt, R.M. \& Sheath, R.G. (2013): Identity and phylogenetic placement of Spirogyra species (Zygnemaophyceae, Charophyta) from California streams and elsewhere. - Journal of Phycology 49: 588-607.

Stancheva, R.; Sheath, R.G. \& Kociolek, J.P. (2016): New freshwater gomphonemoid diatoms from streams in the Sierra Nevada Mountains, California, USA. Phytotaxa 289: 118-134.

StePANeK, J.G. \& Kociolek, J.P. (2013): Several new species of Amphora and Halamphora from the western USA. - Diatom Research 28: 61-76.

TAlavera, G. \& CASTRESANA, J. (2007): Improvement of phylogenies after removing divergent and ambiguously aligned blocks from protein sequence alignments. Systematic Biology 56: 564-577.

Tamura, K.; Peterson, D.; Peterson, N.; Stecher, G.; Nei, M. \& KUMAR, S. (2011): MEGA5: molecular evolutionary genetics analysis using maximum likelihood, evolutionary distance, and maximum parsimony methods. - Molecular Biology and Evolution 28: 2731-2739.

Thomas, E.W. \& KocioleK, J.P. (2015): Taxonomy of three new Rhoicosphenia (Bacillariophyta) species from California, USA. - Phytotaxa 204: 1-21.

TsChermaK-Woess, E. (1979): Zur Kenntnis von Tetrasporopsis fuscescens. - Plant Systematics and Evolution 133: 
$121-133$

Tschermak-Woess, E. \& Kusel-Fetzmann, E. (1992): A new find of Tetrasporopsis fuscescens (A. Braun ex Kützing) Lemmermann (Chrysophyta) in Austria, and some additional observations. - Archiv Protistenkunde 142: $157-165$.

Wehr, J.D.; Stancheva, R.; Truhn, K. \& Sheath, R.G. (2013): Discovery of the rare freshwater brown alga Pleurocladia lacustris (Ectocarpales, Phaeophyceae) in California streams. - Western North American Naturalist 73: 148-157.

WhitFord, L.A. (1976): A change in name for Tetrasporopsis perforata (Whitford) Bourrelly. - Phycologia 15: 101-101.

Yang, E.C., Boo, G.H.; KIm, H.J.; Cho, S.M.; Boo, S.M.; Andersen, R.A. \& Yoon, H.S. (2012): Supermatrix data highlight the phylogenetic relationships of photosynthetic Stramenopiles. - Protist 163: 17-231.

Yoon, H.S; Hackett, J.D. \& Bhattacharya, D. (2002): A single origin of the peridinin-and fucoxanthin-containing plastids in dinoflagellates through tertiary endosymbiosis. - Proceedings of the National Academy of Sciences USA 99: 11724-11729.

ZwickL, D.J. (2006): Genetic algorithm approaches for the phylogenetic analysis of large biological sequence datasets under the maximum likelihood criterion. 1-115 pp., PhD dissertation, University of Texas at Austin, Austin.

(C) Czech Phycological Society (2019)

Received February 27, 2019

Accepted May 20, 2019 